\title{
DISSEMINATING INFORMATION ON COVID-19 TO RURAL DWELLERS THROUGH TRANSLATION: A PANACEA TO COVID-19 SPREAD
}

\author{
Fetnani Cecilia
}

\begin{abstract}
The ravaging coronavirus has been declared a pandemic by the World Health Organization (WHO). Its rate of spread and mortality is alarming. To worsen matters, there is no cure, no vaccine presently, though clinical trials are going on. The economies of different countries have been shut down; people are being isolated and quarantined. Everybody has been advised to stay home and stay safe. For developing countries like Nigeria, the only safeguard to mitigate the crazy impact of the pandemic is to adhere to the precautionary measures outlined by health experts - physical distancing, wearing of facemasks, use of sanitizers, maintaining personal hygiene and avoiding social gatherings. Information on COVID-19 needs to reach all Nigerians no matter their location or level of literacy if the impact would be mitigated. Nigeria is a multilingual society so the COVID-19 information needs to be available to all linguistic groups especially those in the rural areas. This paper discusses the dissemination of information on COVID-19 to rural dwellers through translation. The focus here is the Igbo in the South Eastern part of Nigeria. The paper examines translation and terminology, then goes on to give the Igbo version of about 117 COVID-19 terms employing different methods of term creation like equivalence, composition, naturalisation, idiomatic expressions and explicative modulation. With these, the rural Igbo speakers can understand what COVID-19 is all about, the inherent dangers and the precautionary measures to take in order to stem the tide and preserve lives. Some recommendations were also made to help the containment of the pandemic.
\end{abstract}

Keywords: coronavirus, information, translation, terminology, language

\section{Introduction}

There had been series of life threatening diseases that have attacked the human race among which are: HIV/AIDS, SARS, MERS and EBOLA. The latest amongst them is the corona virus disease. The coronavirus disease popularly known as COVID-19 started towards the end of 2019. The first case of COVID-19 was found in Wuhan, China, where the outbreak started. The virus is called corona because it looks like a crown. CO -corona, VI - virus, D - disease while -19 points to the year it was discovered. It has spread very rapidly to almost all the countries in the world which led the World Health Organization (WHO) to declare it a pandemic disease. As at May 13, 2020 by 16.34 GMT, worldwide, there are $4,390,382$ confirmed cases, 1,633,862 recovered and 295,334 deaths. That leaves us with 2,461,186 active cases [17]. The infection rate continues to rise by the day.

It is taking a huge toll on families, societies, health systems and economies around the world, and for as long as the virus threatens any country, the entire world is at risk. To the best of our knowledge, there are no specific vaccines or treatment for COVID-19. However, there are many ongoing clinical trials evaluating potential treatments. The best way, therefore, is to prevent and slow down transmission by being well informed about the COVID-19, the causes, symptoms and mode of transmission and precautionary measures that should be taken. 
For one to be well informed and be able to digest all the necessary information about COVID-19, there is the need for all necessary information on the deadly disease to be disseminated in the language of the immediate environment or mother tongue. Most of the people residing in the rural areas are either semiliterates or illiterates in English language. Ironically, the information disseminated concerning the deadly COVID-19 is in English language, hence there is an urgent need to translate all the available literature in English into Nigerian indigenous languages to carry the rural dwellers along. The COVID-19 index case was diagnosed in Lagos on February $27^{\text {th }}$ and as at May 13, 2020, by 16.34 GMT, there are in Nigeria, 4,787 total cases, 3,670 active, 158 deceased and 959 recovered [17].

In Nigeria, there are over 450 languages spoken and if all the available literature on COVID-19 is translated into all the indigenous languages in Nigeria, it will prevent and slow down the rate of transmission. The crux of this paper, therefore, is to translate some texts on symptoms and prevention of COVID-19, assemble terms related to it and create terms where necessary. Our sources were mainly the internet, dictionaries, the media - print and electronic.

\section{Multilingualism and Nigeria}

Multilingualism is a linguistic concept used to describe a situation in which an individual, a group or a nation uses more than two languages in communicating national or group needs.

Similarly, Nigeria harbours a multiplicity of ethno linguistic groups; hence Nigeria is a multilingual nation. In Nigeria, there are three major languages, Hausa, Igbo and Yoruba while a lot of non-major languages are developing.

\section{Igbo language}

Igbo language is the principal native language of the people in the South Eastern part of Nigeria. Reference [7] explains that Igbo belongs specially to the Igboid group which consists of Igbo and other related languages. It has about 45 million speakers and is made up of over 20 dialects, though mutually intelligible. It is presently spoken Abia, Anambra, Ebonyi, Enugu, Imo and parts of Delta and Rivers States of Nigeria.

\section{Need for all to be adequately educated and informed about COVID-19}

One of the fastest means of developing a nation is communication - the transmitting and receiving information, ideas, feelings and thoughts. According [11], any transfer of information which has a direct and deliberate impact or influence upon a people's social, economic or political welfare, has considerable impact on the thoughts and conduct of the people. Reference [6] concludes therefore that it is absolutely necessary for the people to know and understand issues, proposals, plans and policies being made for their own good. This underlines the emphasis that this paper is placing on sending the COVID-19 message to all and sundry irrespective of language or location.

In order to succeed in our health information dissemination, it is necessary that accurate and sufficient information be provided in our indigenous languages, in this case, Igbo language, to enable the nonEnglish speakers to be aware of the symptoms, prevention and contend with the challenges of the COVID-19. Understanding all about covid-19 in the indigenous language will help people's attitude towards those that have been infected with the deadly disease. Stigmatization will be reduced to the barest minimum and infected people will willingly present themselves for adequate treatment. Similarly, Adequate education and information will help the people to be conscious of the danger of exposing themselves to infection, appreciate government's effort and then obey the instructions on the dos and don'ts of the disease. It will also help in boosting the socio-economic standard of the people. NonGovernmental Organizations and other governmental agencies will have literature on COVID-19 terms in Igbo which will assist them in reaching out to the rural dwellers, discussing and disseminating the much needed information on all aspects of the disease.

\section{Translation and Terminology}


Translation has been defined in several ways by different linguists and translators. We will go by [2] that says, "Translation is the rendering of a Source language (SL) text to a Target language (TL) so as to ensure that the surface meaning of the two will be approximately similar and the structures of the SL will be preserved as clearly possible but not so closely that the TL meaning will be seriously distorted".

A history of world culture from the perspective of translation reveals a constant movement of ideas, information and of cultures constantly absorbing new influences because of the work of translation. In multilingual nations such as Nigeria and Ghana, translation has come to acquire another role: it functions as an instrument of political consciousness and national unity. Through translation, the federal, states and local governments make their policies and programmes accessible to their numerous linguistic groups that make up the entire country. However, translation works with terminology.

Terminology is the study of terms. Terms are very important to the translator as it equips him to do his job faster. A translator, as a matter of necessity, relies on his own ingenuity and imaginativeness in order to originate and generate terms and equivalence in the mother-tongue. In translating a corpus, the translator needs to choose appropriate terms that correspond with the source language text. We have said earlier on that translation and terminology are interwoven and therefore it would not be and therefore it would not be an overstatement to say that terminology is very essential in, nay central to, translation practice.

\section{Translation of text on Coronavirus (COVID-19)}

We made attempt to translate a text on coronavirus spread, symptoms and prevention. The Igbo translation is placed side by side the English text.

Our sources were mainly from the internet [18]-[20].

What is Coronavirus or COVID-19?

Coronavirus is a very serious sickness that affects the respiratory system and lungs. It is called COVID-19 because CO stands for corona, VI stands for virus, D for disease and 19 for 2019.

When someone has COVID-19, they start coughing and have a fever and they are unable to breathe properly.

There is no medicine for COVID-19 yet. But people who catch it can become well again if they are treated very early in a hospital with good care from doctors and nurses. Many people in Nigeria who were sick with COVID-19 are now well because they were treated early.

If people who catch COVID-19 don't get treated quickly, then they become very sick and die from it.
Gịni bụ ọrịa njekorona (ỌNK-19)?

Ọịa njekorona bụ oke ọịa na-emetụta usoro iku ume na ngụ. A na-akpọ ya ọịa njekorona (ỌNK19), maka Ọ na-anọchite Ọía, N na-anọchite Nje, K na-anọchite Korona ebe 19 na-anọchite 2019.

Mgbe mmadụ nwere ọrịa njekorona (ONK-19), ha na-ebido ịkwa ụkwara, ahụ ha na-adịkwa ọkụ, ọ na-arakwa ha ahụ iku ume nke ọma.

Enwebeghi ọgụ e ji agwọ ọịa njekorona (ỌN19). Mana ndị butere ya nwekwara ike gbakee maọbụrụna a gwọo ha nke ọma n'ụlọogwụ site nlezi na nlekọta nke ndị dọkịta na ndị nọsụ. Ọtụtụ ndị Naijiria butere ọịa njekorona (ỌNK-19) agbakechaala makana e bidoro n'oge gwọwa ha.

Ọbụrụna ebidoghi n'oge gwọwa ndị butere ọrịa njekorona (ỌNK-19), ha abịa rịawa nnukwu ọịa, ha nwekwara ike si otu ahụ nwụọ. 
How do people catch COVID-19?

People catch COVID-19 through these ways:

When you inhale the droplets of an infected person when they sneeze.

When you inhale the droplets of an infected person when they cough.

When you touch a person who is sick with COVID-19, the surfaces they touch and then you touch your face.

If you don't do any of these, then you won't catch COVID-19.

Who can catch COVID-19?

Everyone can catch COVID-19, but it affects these people more...

Older people

People who are sick with other disease like diabetes, heart disease, etc

Children who are exposed to infected people and areas can contract the virus and have severe symptoms.

It is important to protect all children from contracting COVID-19 including people with disability, pregnant women, refugees and migrants, marginalized and vulnerable groups like people who are internally displaced.

How can I protect myself from catching COVID19 ?

There are few smart things you can do so that you don't catch COVID-19...

Always wash your hands with soap and clean running water for at least 20 seconds.
Kedu ka ndị mmadụ si ebute ọrịa njekorona (ỌNK-19)?

Ndị mmadụ na-ebute ọrịa njekorona site n’ụzọ ndị a:

Mgbe I kuuru ihe si n’uzere onye bu ọịa ahụ.

Mgbe I kuuru ihe si n'ụkwara onye bu ọrịa ahụ kwara.

Mgbe I meturu onye na-arịa orịa njekorona aka, metu elu ebe ha meturu aka bịazie metu aka n'íhu gi.

Ọbưrụna I meghi otu n'íme ihe ndị a, I gaghị ebute ọịa njekorona (ONK-19).

Ònyé nwere ike ibute ọịa njekorona (ỌNK-19)?

Ónyé ọbụla nwere ike ibute ọrịa njekorona, mana o ka emetụta ndị a...

Ndị okenye

Ndị nwere ọrịa ndị ọzọ dị ka ọrịa mamịị̣, ọrịa obi dgz.

Ụmụaka ndị ha na ndị bu ya na ebe bu ya nwere mmekorịta, nwere ike bute orịa njekorona (ONK19), bịazie nwee óké mgbáàmà.

Ọ dị mkpa ichekwa ụmụaka niile site n'ibute ọịa njekorona (ONK-19) tinyere ndi nwere nkwarụ, ndị dị ime, ndị gbara ọsọ ndụ, ndị mbimbi, ndị a na-akpapụru akpapụ, na ndị na-enweghi nchekwa dị ka ndị a chụpụrụ n’ebe ha.

Kedu ka m ge-esi echekwa onwe m ka m hapụ ibute ọịa njekorona (ONK-19)?

E nwere ihe ole na ole I nwere ike iji àkọ mee ka I hapụ ibute ọịa njekorona (ỌN-19)...

Were ncha kwụọo aka gị na mmiri na-agba agba opekatampe ntabi anya iri abụọ. 
No shaking of hands.

Cover your mouth and nose with flexed elbow or tissue when you cough or sneeze.

Dispose the used tissue immediately into a closed bin.

Sanitize your hands using an 'alcohol-based sanitizer' always.

Avoid touching your eyes, nose and mouth

If you traveled from a place that is affected by COVID-19 or you come in contact with someone who is infected with COVID-19, you need to take responsibility by isolating yourself so that you don't infect others.

During self-isolation:

Stay in an isolated room with windows for 14 days.

If you experience any symptoms like cough, fever or difficulty in breathing, a call should be made to the health authorities to take you for treatment.

When you are in isolation, don't be worried or afraid. Try to keep yourself busy by e.g reading, writing stories, singing, exercising and so many other fun things.

Cleaning touched surfaces and objects.

Staying at home when you are sick.

Avoid crowded areas.

Keep a safe distance of about one meter away from people including a sick person.

So if you have a fever, cough or difficulty in
Ekwekwala n'aka.

Were njikọta mkpemkpeaka gị maọbụ tishuu kpuchie imi na ọnụ gị mgbe I na-ákwà ụkwara maọbụ ama uzere.

Tụfuo tishuu ahụ ozugbo ozugbo n'ihe nkwafu dọtị nwere okwuchi

Were sanịtaịza nwere akọhọlụ na-ehicha aka gị mgbe ọbụla .

Gbanahụ imetu aka n’anya, imi na ọnụ gị.

Ọbụrụna I si ebe ọịa njekorona (ỌNK-19) meturưla, maọbụ na gị na onye bu ọịa a meturu ahụ, I kwesiri ịhụ ya dị ka ihe I ga-eme site n‘ịkpapụ onwe gi ka I hapụ ibunye ya ndị ọzọ.

N`oge mkpapụ onwe:

I ga-anọ n'ụlọ mkpapụ nwere mpio (windo) ruo abalị iri na anọ.

Ọbụrụna I nwee mgbáàmàọịa dị ka ụkwara, ahụ ọkụ maọbụ I nwee nhịamaahụ n'íku ume, I gaakpọ ndị ợụ ahụike ka ha kpọrọ gị maka ogwụgwọ.

Mgbe I nọ na mkpapụ onwe, atụkwala egwu maọbụ nwee ahụ mgbakasị. Hụ na o nwere ihe I na-eme dị ka igụ akwụkwọ, ide edemede, igụ egwu, imeghari ahụ maka mgbatịsị oxpụkpụ na akwara, na ọtụtụ ihe ndị ọzọ na-enye obi uto.

Ihichasị elu ihe na ebe e meturu aka.

Ịnọ n‘ụlọ mgbe ahụ na-adịghị gị.

Sọo ebe igwe mmadụ nọ.

Hụ na I nọ otu ntụ mita site n'ebe onye ọzọ nọ tinyekwara onye ahụ na-adịghị.

Ọbụrụna I nwee ahụọkụ, ụkwara maọbụ 
breathing, tell your parents or guardian early so that they can seek medical guidance for you.

How to wash your hands properly:

1) Wet your hands with running water.

2) Apply enough soap to cover your wet hands.

3) Scrub all surfaces of your hands thoroughly - including the back of your hands, your wrists, between fingers and under finger nails - for at least twenty (20) seconds.

4) Pay particular attention to your thumbs.

5) Press finger tips into the palm of each hands.

6) Rinse thoroughly with running water.

7) Dry hands with a clean cloth or air them to dry.

An easy way to time it is by singing the full happy birthday song twice or the ABCDEFG... song.

When should I wash my hands?

In general and in the context of COVID-19 prevention, you should always wash your hands at the following times:

After blowing your nose, coughing or sneezing.

After visiting a public area including public transportation, market and place of worship.

After touching surfaces outside of your home including money.

Before and after eating.

Before, during and after taking care of a sick person.

After using the toilet. nhịamaahụ n'íku ume, gwa nne na nna gị maọbụ ndị na-elekọta gị ọsịisọ ka ha nwee ike ibido n’oge chọwa ọgwụgwọ gị.

Otu e si akwọ aka nke ọma:

1) Mee mmiri n'aka gi na mmiri na-agba agba.

2) Tee ncha nke ọma $n^{6}$ ebe niile mmiri meturu gị n'aka.

3) Kwochasia elu aka gị niile nke ọma, tinyere azụ aka gị, njikọ mkpưrụaka gị na ime mvọ gị - ihe dị ka ntabi anya iri abụọ.

4) Lebara mkpụrụaka ukwu gị anya nke ọma.

5) Were mkpụrụaka anọ gị ha kwozie oba aka gi abuo.

6) N̄achaa aka gị nke ọma na mmiri na-agba agba.

7) Were ákwà dị ọcha hichaa aka gị maọbụ hapụ ya ka ikuku kọo ya.

Ụzọ dị mfe iji hazie oge ọkụ̂kọ́ à bụ ịgụ ukwe ụbọchị omụmụ ma ọ bụ ABCHD...

Kedu mgbe m ga-akwọ aka m?

Mgbe niile ọkacha n'oge mgbochi ọịa njekorona (ỌNK-19), I ga na-akwọ aka gị n‘oge ndị a:

Mgbe I zichara imi, kwacha ụkwara maọbụ machaa uzere.

Mgbe I gachara n'ọgbọ, tinyere ọdụ ụgbọala ọha, ahịa na ebe okpukperechi

Mgbe I puru apụ metuchaa ihu ihe aka, tinyere ego.

Tupu na mgbe I richara nri.

Tupu, mgbe I na-ele na mgbe I letachara onye ọịa.

Mgbe I gachara mposi. 
After handling gabbage.

After touching animals and pets.

After changing babies' diapers or helping children use the toilet.

When your hands are visibly dirty.

Don't believe what is not true about COVID-19.

Don't use chloroquine or buy other drugs to treat COVID-19. Allow medical experts to tell you what to take.

People should not take alcohol against COVID19.

COVID-19 cannot be transmitted through mosquito bites.

Taking a hot bath does not prevent COVID-19.

Don't stigmatize people who are infected.

When you are sick, you can pray. But you must also call the health authorities to request for a test so that you can be treated medically and receive good care from doctors and nurses.

COVID-19 does not only affect rich people.
Mgbe I kpofuchara dọtị.

Mgbe I metuchara ụmụ anụmanụ àkà.

Mgbe I wapụchara ụmụaka pampasị nakwa mgbe I nyeere ha aka I ga mkpochi(ịnyụ nsị).

Mgbe o doro anya na aka gị dị dọtị.

Ekwenyekwala n'ihe abụghị eziokwu maka ọịa njekorona (QNK-19).

Ańụkwala klorokwin maọbụ zụrụ ọgwụ ndị ọzọ iji gwọo ọịa njekorona (ONK-19). Hapụ ndị ọrụ ahụike ka ha gwa gị ihe I ga-anuụ.

Ndị mmadụ anukwala ákọ̀họ́lụ iji megide ọrịa njekorona (ONK-19).

Anwụnta anaghị atanye ọịa njekorona (ONK19).

Isa oke mmiri ọkụ anaghị egbochi ọịa njekorona (ONK-19).

Akpapụkwala ndị bu ọrịa njekorona (ỌNK-19).

I nwere ike kpee ekpere mgbe I na-arịa orịa. Mana I ga-akpọkwa ndị orụ ahuike ka ha nyochaa gi ahụ ka e nwee ike gwọo gị n'ụzọ ziri ezi ka inwetakwa nlekọta n'aka ndị dọkịta na ndị nọsụ.

Ọ bụghị naanị ndị oggaranya ka ọrịa njekorona (QNK-19) na-arịa.

\section{ENGLISH/IGBO COVID-19 TERMS AND EXPRESSIONS}

\section{ENGLISH}

1. Admitted

2. Alcohol-based hand sanitizer

3. Ambulance

4. Asymptomatic

5. Border protection

6. Bullying

7. Challenges
IGBO

Ínyē àkwà n'ụ́lọọogwụ̀

Sànịtáízà nwéré ákộhộlụ̣

Ứgbọaàlà mòú òzù/ńdị mérứrụ́ āhụ̣

Énwēghī (V) mgbáàmà (N)

Ńchékwá ókè

Íkụ íhé

Ị́he ímà áká/Áká m̄gbā

\section{METHODS OF TERM}

CREATION

Explicative modulation

Explicative modulation

Explicative modulation

Composition

Equivalence

Equivalence

Idiomatic rendering 
8. Cleaning surfaces

9. Cold

10. Close contact

11. Contact

12. Contact tracing

13. Communicable disease

14. Community spread

15. Community trace

16. Community transmission

17. Contamination

18. Crowded area

19. Daily disinfectant

20. Day income earners

21. Diabetes

22. Diagnosis

23. Difficulty breathing

24. Discharge

25. Disposable gloves

26. Draw samples

27. Droplets

28. Enforcement team

29. Epidemic

30. Essential services

31. Face mask

32. Fatality rata

33. Financial support

34. Flexed elbow

35. Flu (Influenza)

36. Flu-like

37. Front-line workers

38. Fumigation

39. Good ventilation

40. Hand glove

41. Health authority

42. Health-care delivery

43. Health-care system

44. High touch surfaces

45. Homeland security

46. Index case

47. Indigents

48. Infectious

49. Infected

50. Infected persons

51. Inhale droplets

52. Intensive Care Unit (ICU)

53. Inter-ministerial Committee/

54. Isolated room

55. Isolation

56. Limit close contact

57. Limited movement of people

58. Loss of smell

59. Loss of taste

60. Lungs

61. Material support

62. Medical guidance

63. Medical protocol

64. Meticulous in Hand washing

65. Mobile court

66. National Centre for Disease Control (NCDC)

67. Oxygen concentrator

68. Palliatives
Ńhīchā élú/íhú íhē

Óȳ̄

ńnọkoọtá ộnụ̂

Ńchịkộtá áhụ̂innộkèté

Ńchộpụtá ńdị há nà ndị bú ộịà chịkoọ̀tàrà àhụ́

Órịà na-éfé èfè

Ḿbúfè (N) n'ogbè (VP)

Íchộpụ̀tà ńdị́ bú ộrịà n'ógbè

Ḿbúfè n'ogbè

Ḿbúté ñjēoọrịà

Ébé ńdị ḿmádụ jùrù èjú

Íjī mònúñ̄ē hícháá kwà ụ́bọ̀chị

Ńdị ọ́rụu ụ̂bọ̀chị

Ộrịa shúgà/ọ́rịạ mámịịị

Úsòrò ńchộụ̣tá

Ǹràmàhụ́ n'íkù úmé

İsỊ ónyé gbákéré n’ụlọoọgwụ̀ làwá

Ḿkpùchíákā éyié àtứfùó

Îmịtà (site n'àhụ́) íhé é jì èmé ńnyòchá

Ǹsì n'ímí nà ộnụ̂ (bụ́pụtá) $(\mathrm{Pp})$

Ńdị ộrụ́ ộtáwáíkē

Órịā òzùrù òbòdò

Ọ́rụ ńdị dị óké mókpà

M̀kpùchí īhū

ógó ộnwụ̣

Ínyē ńkwàdó égō

M̀kpémòkpèákā á pịàjìrì àpịájí

Ọ́rịà òfùfè

Ọirià ńdị dị kà ọ́rịá òfùfè

Ńdị nọ́ n'isí ộự áhựíkē

Ọ́gwụ ḿgbòchí (ébé)

Ébé ìkùkù nà-ạábàtá ǹ̀è ộmá

M̀kpùchí ākā

Ńdịísī ộrụ áhựíkē

Ògwựgwọ́ ộrịà

Úsòró ọggwựgwọ́ ộrịà

Ébé á nà-èmétúkárị ákā

Ńdị n̄chē òbòdò

Ónyé m̄bụ̄ bútéré ộrịà

Ńdị ógbènyè ộnụ́ntụ̣

Ífè èfè (VP)

Ḿbúfè

Ńdị bụ ộịạa

Íkùrù íhé é sí n“ímí nà ộnụ̂ (bụpụtá)

Ébé ńdétó ńdị ộrịà há dị jìsì óké íkē

Kọ̀mìtî ộrịà ńjékòrónà

Ứlọ̀ ḿkpápụ̀ (màkà ńdị bú ộrịa òfùfè)

Ḿkpápụ

Bèlátá óké ńnọkèté ộnū

Enwēghī óké ńgághị

Ánụghị̣ ńsì

Ánụ̂ghị ụ̣tọ́

Ǹgụ̀

Ínyē ńkwàdó íhé ènyèmáká

Úsòrò ńdúzí màkà àhựíkē

Ńdị òtù àhụíkē

Ńlézí ányā n'ọ̀kwụ́kwộ áká

Ứlọíkpē ḿbúghárị

Séńtà ná-áhụ́ màkà ḿgbòchị ộịà

Ìgbé búrú íbù màkà ikùkù ńdụ

Ńgwá ǹnyèmáká
Equivalence

Equivalence

Equivalence

Equivalence

Explicative modulation

Equivalence

Composition

Explicative modulation

Equivalence

Equivalence

Explicative modulation

Explicative modulation

Equivalence

Equivalence

Equivalence

Equivalence

Explicative modulation

Equivalence

Explicative modulation

Composition

Equivalence

Explicative modulation

Explicative modulation

Equivalence

Equivalence

Equivalence

Explicative modulation

Equivalence

Explicative modulation

Idiomatic rendering

Equivalence

Explicative modula

Equivalence

Equivalence

Equivalence

Equivalence

Explicative modulation

Equivalence

Explicative modulation

Idiomatic expression

Composition

Equivalence

Equivalence

Explicative modulation

Explicative modulation

Equivalence

Explicative modulation

Equivalence

Equivalence

Equivalence

Equivalence

Equivalence

Equivalence

Explicative modulation

Explicative modulation

Equivalence

Idiomatic rendering

Equivalence

Equivalence

Explicative modula

Equivalence 

69. Pandemic
70. Para-medical personnel
71. People with disability
72. Physical distancing
73. Personal Protective Equipment (PPE)
74. Plague
75. Positive hygiene
76. Precaution
77. Presidential task force on COVID-19
78. Presidential Task Fund (PTF)
79. Pressure monitor
80. Prevention
81. Protect and contain the deadly disease
82. Public enlightenment
83. Public health threat
84. Public places
85. Refugees

86. Returnees

87. Regular Hand washing

88. Running water

89. Sanitizer

90. Self-monitor

91. Security

92. Security agencies

93. Security beef-up

94. Seek medical care

95. Self-isolation

96. Service providers

97. Severe symptoms

98. Signs of COVID-19

99. Skeletal services

100. Social distancing

101. Stigmatization

102. Suspected cases

103. Symptoms

104. Take responsibility

105. Test

106. Test negative

107. Test positive

108. Transmission

109. Travel history

110. Quarantine

111. Vaccination

112. Ventilator

113. Victim Support Fund (VSF)

114. Virus

115. Vulnerable group

116. Work-from-home

117. World Health Organization (WHO)
Ộrịā òzùrù ụ̀wà

Ńdị ǹnyèáká n'ọ́rứ àhứíkē

Ńdị nwéré ńkwárụ́

Ńnọ́kègá/Ánọghị ǹsó

Ńgwá $(\mathrm{N})+$ ḿgbòchí $(\mathrm{N})$

Órịà

Ézị ị̂ị ộchá (Adv.p)

İdị àkọ́

Ńdị ộuụ ộtáwáíkē ké Prézídéǹtì màkà

Ộrịà ńjékòrónà

Égó ḿmáwàpụtá màkà ộuụ

Ńgwá ńlélé ógó ǹkùúmé

Mgbòchí

Chèkwáá ma kwụsị ọ́rịạ oọjọọ̣ à

Ńkúsí nyé ọ̀hànézè

Ớrịa chééré ọ̀hànézè áká m̄gbā

Ébé ộtựtú ḿmádụ̀ nà-àgbàkọ̀

Ńdị gbárá ộsọ́nụ̣ (NP)/Ńdị réfùjúù

Ńdị lộtárá álọ́tá (Adv.p)

Ò̀wwụkwọ́ áká kwà mìgbè kwà m̀̀gbè

Ḿmírí ná-ágbá ágbā

Sànịtáịzà

Ńlébàrá ónwé ányá

Ńchékwá

Éjéńsì/ńdị na-áhụ́ màkà ńchékwá

Ḿkpàchí ńchékwá

Gàá ựlọọg gụ

Ḿkpápụ̀ ónwé

Ńdị ộrụ́ áhựíkē

Ńnúkwú $(\mathrm{N}+\mathrm{N})$ ǹjìrìmárá

Ǹjì̀̀márá ọ́rịa ǹjékòrónà (ONK-19)

Ńrụ́bìrí ợụu

Ńzèré $(\mathrm{N})$ ọgbákọ̀ $(\mathrm{N})$ /îgwé ḿmádụ̀

İsộ ásọ́ (VP)

Ńdị á nà-ényò nà bù ộrịà

Njjììmárá

Rụọo ợuụ dịịirị gị

Ílē àhự/ínyòchá

Ébūghī ộịà

Íbū ộrịà

Ḿbúfè

Òtù é sì gáá ǹjèm̀

Ńkéwàpụ́

Ọgwụ̀ ḿgbòchí

Ḿkpọ ìkùkù

Égó ḿmáwàpụttá màkà ńdị óríbìdòrò

Váịiọ̀s (Ǹjé váị̂ọ̣s)

Ńdị ná-ébútékárị ộrịà

Ísī n'ụ́lọ̀ àrụ́ ộrụ̣

Òtù múbạụwwà ná-áhụ́ màkà àhụíkē
Explicative modulation

Explicative modulation

Equivalence

Equivalence

Composition

Equivalence

Composition

Idiomatic rendering

Explicative modulation

Explicative modulation

Explicative modula

Equivalence

Equivalence

Equivalence

Explicative modulation

Explicative modulation

Composition/

Naturalization

Composition

Equivalence

Equivalence

Naturalization

Equivalence

Equivalence

Explicative modulation

Equivalence

Equivalence

Equivalence

Equivalence

Composition

Equivalence

Equivalence

Composition

Composition

Explicative modulation

Equivalence

Explicative modulation

Equivalence

Equivalence

Equivalence

Equivalence

Explicative modulation

Equivalence

Equivalence

Equivalence

Explicative modulation

Naturalization

Explicative modulation

Explicative modulation

Explicative modulation

\section{Methods of term creation}

It was only after due research for existing and documented Igbo equivalent terms had been exhausted that we resorted to term creation. Terms are not created haphazardly. For a term to be created, some methods must be employed. In the creation of terms, attempts have been made to ensure that the created terms are 
both transparent and specific, since they are cognitive tools for understanding phenomena. One of the methods of term creation used was Dubuc's and it is classified into direct and indirect methods. In the present glossary, only the direct method has been used. The predominant aspect of the direct method used is composition, which involves joining two or more full meaning words. In addition to the above composition method, care has been taken to analyze component terms into their nuclear elements before the terminal composition. Other techniques used include: Naturalization, equivalence, explicative modulation, idiomatic rendering.

There are still other methods that are not used here but which are worthy of mention. They include:

A. Semantic extension: This means extending the meaning of a word. It can be done in three ways:

1) logical relationship

clay pot : ìtè àjà

a drink : mmáyá

latest fashion : ébé ánọ̀

in my view : n' úchè $m$

bomb : ógbúnìgwè

2) analogy e.g.

Volkswagen : ọ́kpụ̀rụkkpụ̀ mbè

Network : álụgghàà̀ù

3) assimilation e.g.

motor : mótò

diapers : pampasi

B. Adaptation: Here, there is a radical change in the sound or the pronounciation of the term in the target language to suit the orthography of the language e.g.

copying: nkọ́pì

pound: pọoọm

C. Back formation: This is chopping off certain segments of a word e.g.

laboratory : láábụ̀

D. Acronyms: This is using the first letter of component words to form a term e.g.

ọ́ria njé kóróna - ỘNK

ima ḿmádụ ợụ́ma - ịmọ

E. Hybridization: This is the inter-marriage of two languages e.g. itè pot 


\section{Explanation of the techniques of term creation used}

A. Naturalization: This is to introduce a word from the source language into the target language using the orthography of the target language.
1. Sanitizer
Sànịtáízà
Naturalization
2. Refugees
Ńdị gbárá ộsọ́nụ̣ (NP)/Ńdị réfùjúù
Composition/
3. Tissue
Tishuu
Naturalization
4. Nigeria
Naijiria
Naturalization
Naturalization

B. Composition/compounding: is a process of joining two or more meaningful independent words to form a single term. It does not involve words from a particular part of speech, words from different parts of speech can also be stringed together. Examples include:
1. Asymptomatic
Énwēghī $(\mathrm{V})$ ǹjì̀ìmárá $(\mathrm{N})$
Composition
2. Community spread
Ḿbúfè (N) n'ogbè (VP)
Composition

C. Equivalence: These are terms that have their equivalents in the target language. Examples :

1. Border protection

2. Bullying

Ńchékwá ókè

İkụ íhé

Equivalence

Equivalence

D. Explicative modulation/expansion of meaning: This technique is applicable where there is lack of equivalent in the target language. Using explicative modulation - explaining the meaning in the target language solves the problem. Examples:

1. Alcohol-based hand sanitizer

2. Ambulance

\section{Sànịtáịzà nwéré ákọ̀họ́lụ̀}

Ứgbọaàlà mbú òzù/ńdị mérứrú āhụ̄
Explicative modulation Explicative modulation

E. Idiomatic rendering: According to Ohaike (2010), idioms are a succession of words whose meanings are not obvious through the knowledge of the individual meanings of the constituent words but must be learnt as a whole. It is an expression that is peculiar to a society. It is a form of word coinage which leads to the introduction of new words or extension of meaning of existing words. Example:

1. Meticulous in hand washing

2. Precaution
Ńlézí ányā n‘ọ̀kwụ́kwộ áká Î́dị àkọ́
Idiomatic rendering

Idiomatic rendering

\section{Recommendations}

From the foregoing, the following measures are recommended:

A. All text or literature on COVID-19 in foreign languages should be translated into our indigenous languages.

B. There is the urgent need to create COVID-19 and related terms in our indigenous language.

C. Health care providers should be trained in the use of our indigenous languages in relating to their patients and the public at large. 
D. Government and Non-Governmental Organizations (NGO) should mobilize and sponsor translators and language experts to translate into our indigenous languages any document on COVID-10 in any foreign language.

E. Enough time should be allotted to the use of our indigenous languages in the electronic media in disseminating information to the citizenry especially for those residing in the rural areas.

F. Government and Non-governmental organization (NGO) should sponsor the publication and distribution of translated materials.

G. Our indigenous system of information dissemination (ekwe, ikoro, town-criers etc) should be used in disseminating information on COVID-19 to the rural dwellers.

H. Government should mandate NINLAN to go into aggressive assembling and creation of terms in our indigenous languages.

I. Teachers should be trained and retrained in the use of the indigenous language to meet up with the challenges of teaching health issues in schools.

J. Government should create a parastatal or an agency that would be in charge of terminological development in local languages, translation and documentation of every communication between her and the people.

K. There is the urgent need for our Government to build and furnish our hospitals to world class standard and translators/interpreters employed alongside the health workers.

\section{Conclusion}

The world is being ravaged by the deadly COVID-19. One of the ways to prevent the spread of the deadly disease is information dissemination and this could be achieved through translation. We have contributed our quota in the prevention of COVID-19 by making sure the rural dwellers are abreast with the symptoms of COVID-19 and precautionary measures that should be taken to prevent it by translating text COVID-19 and assembling and creating where necessary some terms related to COVID-19. We have also made some recommendations that if considered, standardized, approved and implemented will go a long way in preventing or curtailing the spread of COVID-19. This will be very helpful especially to African countries like Nigeria where the health systems can in no way cope should the pandemic descend heavily on us like it has done in the developed countries of America and Europe.

\section{References}

Setiawan, Adib Rifqi. (2017, February 24). Penerapan Pendekatan Saintifik untuk Melatihkan Literasi Saintifik dalam Domain Kompetensi pada Topik Gerak Lurus di Sekolah Menengah Pertama. Undergraduate Thesis. Bandung: Universitas Pendidikan Indonesia. URL: http://repository.upi.edu/29074/

Setiawan, Adib Rifqi. (2020, April 21). Lembar Kegiatan Literasi Saintifik untuk Pembelajaran Jarak Jauh Topik Penyakit Coronavirus 2019 (COVID-19). Edukatif: Jurnal Ilmu Pendidikan, 02(01): 28-37. DOI: https://doi.org/10.31004/edukatif.v2i1.80

Setiawan, Adib Rifqi. (2020, March 01). Pendidikan Literasi Finansial Melalui Pembelajaran Fiqh Mu'āmalāt Berbasis Kitab Kuning. Nazhruna: Jurnal Pendidikan Islam, 03(01): 138-159. DOI: https://dx.doi.org/10.31538/nzh.v3i1.522

Setiawan, Adib Rifqi. (2020, January 24). Pembelajaran Tematik Berorientasi Literasi Saintifik. Jurnal Basicedu: Journal of Elementary Education, 04(01): 71-80. URL:

https://jbasic.org/index.php/basicedu/article/view/298 
Setiawan, Adib Rifqi. (2019, December 30). Instrumen Penilaian Pembelajaran Fiqh Mu'āmalāt Berorientasi Literasi Finansial. Eklektik: Jurnal Pendidikan Ekonomi dan Kewirausahaan, 02(02): 258-272. DOI: http://dx.doi.org/10.24014/ekl.v2i2.8117

Setiawan, Adib Rifqi. (2019, December 20). Literasi Saintifik Berdasarkan Kecerdasan Majemuk dan Motivasi Belajar. Media Penelitian Pendidikan: Jurnal Penelitian dalam Bidang Pendidikan dan Pengajaran, 13(02): 126-137. DOI: http://dx.doi.org/10.26877/mpp.v13i2.4913

Setiawan, Adib Rifqi; Puspaningrum, Mita; \& Umam, Khoirul. (2019, December 06). Pembelajaran Fiqh Mu'āmalāt Berorientasi Literasi Finansial. Tarbawy: Indonesian Journal of Islamic Education, 06(02): 187-102. URL: https://ejournal.upi.edu/index.php/tarbawy/article/view/20887

Setiawan, Adib Rifqi. (2019, October 02). Efektivitas Pembelajaran Biologi Berorientasi Literasi Saintifik. Thabiea : Journal of Natural Science Teaching, 02 (02): 83-94. DOI: http://dx.doi.org/10.21043/thabiea.v2i2.5345

Setiawan, Adib Rifqi. (2019, September 30). Instrumen Penilaian untuk Pembelajaran Ekologi Berorientasi Literasi Saintifik. Assimilation: Indonesian Journal of Biology Education, 02(02): 42-46. DOI: https://dx.doi.org/10.17509/aijbe.v2i2.19250

Setiawan, Adib Rifqi; Mufassaroh, Arij Zulfi. (2019, June 28). Menyusun Soal Literasi Saintifik untuk Pembelajaran Biologi Topik Plantae dan Animalia. BIOSFER: Jurnal Biologi dan Pendidikan Biologi, 04(01): 33-40. URL: http://dx.doi.org/10.23969/biosfer.v4i1.1484

Setiawan, Adib Rifqi. (2019, June 26). Peningkatan Literasi Saintifik melalui Pembelajaran Biologi Menggunakan Pendekatan Saintifik. Journal of Biology Education, 02(01): 223-235. URL: http://journal.stainkudus.ac.id/index.php/jbe/article/view/5278

Setiawan, Adib Rifqi; Utari, Setiya; Nugraha, Muhamad Gina. (2017, September 22). Mengonstruksi Rancangan Soal Domain Kompetensi Literasi Saintifik Siswa SMP Kelas VIII pada Topik Gerak Lurus. Wahana Pendidikan Fisika, 02(02): 44-48. URL: https://ejournal.upi.edu/index.php/WPF/article/view/8277/0

Setiawan, Adib Rifqi. (2020, April 20). Menyusun Instrumen Penilaian untuk Pembelajaran Ekologi Berorientasi Literasi Saintifik. Prosiding Seminar Nasional dan Workshop Biologi-IPA dan Pembelajaran Ke-4 (SnoWBel IV): 241-9. ISBN : 978-602-470-170-3 \& e-ISBN : 978-602-470-171-0.

Setiawan, Adib Rifqi. (2020, February 18). Menyusun Instrumen Penilaian untuk Pembelajaran Topik Lingkungan Berorientasi Literasi Saintifik. Prosiding Seminar Nasional Fisika (SiNaFi) 2019: 15-21. URL: http://proceedings.upi.edu/index.php/sinafi/article/view/563

Setiawan, Adib Rifqi. (2020, January 17). Penggunaan Mabadi ‘Asyroh dalam Pembelajaran Biologi untuk Meningkatkan Motivasi dan Hasil Belajar. Prosiding Seminar Nasional Biologi 2019 Inovasi Penelitian dan Pembelajaran Biologi III (IP2B III): 158-164. URL:

http://semnasbiologi.conference.unesa.ac.id/ocs/index.php/semnasbio/IP2BIII/paper/viewFile/11/2 1

Setiawan, Adib Rifqi. (2020, January 17). Upaya Meningkatkan Motivasi Belajar dalam Pembelajaran Ilmu Pengetahuan Alam (IPA) Melalui Bacaan Populer. Prosiding Seminar Nasional Biologi 2019 Inovasi Penelitian dan Pembelajaran Biologi III (IP2B III): 154-157. URL: http://semnasbiologi.conference.unesa.ac.id/ocs/index.php/semnasbio/IP2BIII/paper/viewFile/5/51

Setiawan, Adib Rifqi. (2020, January 17). Penerapan Pendekatan Saintifik dalam Pembelajaran Biologi sebagai Upaya Melatih Literasi Saintifik. Prosiding Seminar Nasional Biologi 2019 Inovasi Penelitian dan Pembelajaran Biologi III (IP2B III): 140-145. URL:

http://semnasbiologi.conference.unesa.ac.id/ocs/index.php/semnasbio/IP2BIII/paper/viewFile/6/19

Setiawan, Adib Rifqi. (2019, October 14). Penyusunan Program Pembelajaran Biologi Berorientasi Literasi Saintifik. Seminar Nasional Sains \& Entrepreneurship VI (SNSE VI): 255-1-8. URL: http://conference.upgris.ac.id/index.php/snse/article/view/255

Setiawan, Adib Rifqi. (2019, May 07). Penerapan Pendekatan Saintifik untuk Melatih Literasi Saintifik dalam Domain Kompetensi pada Topik Gerak Lurus di Sekolah Menengah Pertama. Prosiding Seminar Nasional Fisika (SiNaFi) 2018: 7-13. URL: http://proceedings.upi.edu/index.php/sinafi/article/view/355 
Setiawan, Adib Rifqi. (2019, November 23). Profil Literasi Saintifik Berdasarkan Kecerdasan Majemuk dan Motivasi Belajar. Seminar Nasional Fisika V (SiNaFi 5.0), Universitas Pendidikan Indonesia (UPI). DOI: https://dx.doi.org/10.35542/osf.io/m7n95

Setiawan, Adib Rifqi. (2019, November 23). Menyusun Instrumen Penilaian untuk Pembelajaran Topik Lingkungan Berorientasi Literasi Saintifik. Seminar Nasional Fisika V (SiNaFi 5.0), Universitas Pendidikan Indonesia (UPI). DOI: https://dx.doi.org/10.35542/osf.io/sc6d2

Setiawan, Adib Rifqi. (2019, November 23). Analisis Keabsahan dan Keandalan Science Motivation Questionnaire II (SMQ II) Versi Bahasa Indonesia. Seminar Nasional Fisika V (SiNaFi 5.0), Universitas Pendidikan Indonesia (UPI). DOI: https://doi.org/10.31237/osf.io/6zeph

Setiawan, Adib Rifqi. (2019, October 05). Menyusun Instrumen Penilaian untuk Pembelajaran Ekologi Berorientasi Literasi Saintifik. Seminar Nasional \& Workshop Biologi, IPA, dan Pembelajarannya ke-4 (SnoWBel IV), Universitas Negeri Malang (UM). DOI: https://dx.doi.org/10.13140/RG.2.2.21931.39206

Setiawan, Adib Rifqi. (2019, August 21). Penyusunan Program Pembelajaran Biologi Berorientasi Literasi Saintifik. Seminar Nasional Sains \& Entrepreneurship VI (SNSE VI), Universitas PGRI Semarang (UPGRIS). DOI: https://dx.doi.org/10.13140/RG.2.2.13716.86400

Setiawan, Adib Rifqi. (2019, March 23). Upaya Meningkatkan Motivasi Belajar dalam Pembelajaran Ilmu Pengetahuan Alam (IPA) Melalui Bacaan Populer. Seminar Nasional Biologi 2019 Inovasi Penelitian dan Pembelajaran Biologi III (IP2B III), Universitas Negeri Surabaya (UNESA). DOI: https://dx.doi.org/10.13140/RG.2.2.13087.71847

Setiawan, Adib Rifqi. (2019, March 23). Penerapan Pendekatan Saintifik dalam Pembelajaran Biologi sebagai Upaya Melatih Literasi Saintifik Siswa Sekolah Menengah. Seminar Nasional Biologi 2019 Inovasi Penelitian dan Pembelajaran Biologi III (IP2B III), Universitas Negeri Surabaya (UNESA). DOI: https://dx.doi.org/10.13140/RG.2.2.19798.60484

Setiawan, Adib Rifqi. (2019, March 23). Penggunaan Naḍom Mabādī 'Asyroh dalam Pembelajaran Biologi untuk Meningkatkan Motivasi dan Hasil Belajar. Seminar Nasional Biologi 2019 Inovasi Penelitian dan Pembelajaran Biologi III (IP2B III), Universitas Negeri Surabaya (UNESA). DOI: https://dx.doi.org/10.13140/RG.2.2.33220.37763

Setiawan, Adib Rifqi. (2018, November 24). Penerapan Pendekatan Saintifik untuk Melatih Literasi Saintifik dalam Domain Kompetensi pada Topik Gerak Lurus di Sekolah Menengah Pertama. Seminar Nasional Fisika ke-4 (SiNaFi IV), Universitas Pendidikan Indonesia (UPI). DOI: https://dx.doi.org/10.13140/RG.2.2.23154.04809

Setiawan, Adib Rifqi; Utari, Setiya; Nugraha, Muhamad Gina. (2016, December 17). Mengonstruksi Rancangan Soal Domain Kompetensi Literasi Saintifik Siswa SMP Kelas VIII pada Topik Gerak Lurus. Seminar Nasional Fisika ke-2 (SiNaFi II), Universitas Pendidikan Indonesia (UPI). DOI: https://dx.doi.org/10.13140/RG.2.2.31856.10246/1

Setiawan, Adib Rifqi. (2020, May 12). Introducing the Indonesian Education System. Thesis Commons. DOI: https://doi.org/10.31237/osf.io/ygt5c

Setiawan, A. R. (2020, May 7). Discovering the Fundamental Problem of Four Methods to Analyze Data. Thesis Commons. DOI: https://doi.org/10.31237/osf.io/h953y

Setiawan, Adib Rifqi. (2020, May 6). Menyibak Makna Karya Fadhilaturrahmi. LIS Scholarship Archive. DOI: https://doi.org/10.31229/osf.io/65y4z

Setiawan, Adib Rifqi. (2020, May 6). Discovering the Meaning of Fadhilaturrahmi's Work. Thesis Commons. DOI: https://doi.org/10.31237/osf.io/krf7z

Feldman, DarHalevy; \& Setiawan, Adib Rifqi. (2020, April 24). Education in Israel. Thesis Commons. DOI: https://doi.org/10.31237/osf.io/62shg

Setiawan, Adib Rifqi. (2020, April 18). Musyāfahah al-Qur'ān Melalui Media Elektronik. Thesis Commons. URL: https://thesiscommons.org/ntjp9/ 
Setiawan, Adib Rifqi. (2020, April 14). Jalāl al-Dīn 'Abd al-Roḥmān ibn Abī Bakr al-Suyūṭ̂. SocArXiv. DOI: https://doi.org/10.31235/osf.io/5zf9v

Setiawan, Adib Rifqi. (2020, April 14). Commodification of the Sexuality in Kim Kardashian's Instagram Posts. SocArXiv. DOI: https://doi.org/10.31235/osf.io/kd6au

Velasufah, Whasfi; \& Setiawan, Adib Rifqi. (2020, April 13). Nilai Pesantren Sebagai Dasar Pendidikan Karakter. Thesis Commons. DOI: https://doi.org/10.31237/osf.io/hq6kz

Setiawan, Adib Rifqi. (2020, April 13). Commodification of the Sexuality in Kim Kardashian's Instagram Posts. Thesis Commons. URL: https://thesiscommons.org/mf7nw/

Setiawan, Adib Rifqi. (2020, April 13). مبادئ اللغة العربية. Thesis Commons. DOI: https://doi.org/10.31237/osf.io/2gvjf

Siayah, Syarofis; \& Setiawan, Adib Rifqi. (2020, April 13). A Brief Explanation of Science Education. EdArXiv. DOI: https://doi.org/10.35542/osf.io/2evn3

Siayah, Syarofis; \& Setiawan, Adib Rifqi. (2020, April 13). A Brief Explanation of Science Education. Thesis Commons. DOI: https://doi.org/10.31237/osf.io/wkvsn

Setiawan, Adib Rifqi; \& Ilmiyah, Surotul. (2020, April 13). Multiple Intelligences Based on Neuroscience. Thesis Commons. DOI: https://doi.org/10.31237/osf.io/e9fyu

Setiawan, Adib Rifqi; \& Ilmiyah, Surotul. (2020, April 13). Kecerdasan Majemuk Berdasarkan Neurosains. EdArXiv. DOI: https://doi.org/10.35542/osf.io/rj2fe

Setiawan, Adib Rifqi. (2020, April 9). Islamic Education in Southeast Asia. EdArXiv. DOI: https://doi.org/10.35542/osf.io/dnjqv

Setiawan, Adib Rifqi. (2020, April 9). Islamic Education in Southeast Asia. Thesis Commons. DOI: https://doi.org/10.31237/osf.io/e794d

Ilmiyah, Surotul; \& Setiawan, Adib Rifqi. (2020, April 7). Students' Worksheet for Distance Learning Based on Scientific Literacy in the Topic Coronavirus Disease 2019 (COVID-19). Thesis Commons. DOI: https://doi.org/10.31237/osf.io/fpg4j

Ilmiyah, Surotul; \& Setiawan, Adib Rifqi. (2020, April 7). Students' Worksheet for Distance Learning Based on Scientific Literacy in the Topic Coronavirus Disease 2019 (COVID-19). EdArXiv. DOI: https://doi.org/10.35542/osf.io/wyz5v

Setiawan, Adib Rifqi; \& Ilmiyah, Surotul. (2020, April 7). Lembar Kegiatan Siswa untuk Pembelajaran Jarak Jauh Berdasarkan Literasi Saintifik pada Topik Penyakit Coronavirus 2019 (COVID-19). EdArXiv. DOI: https://doi.org/10.35542/osf.io/h4632

Setiawan, Adib Rifqi. (2020, April 5). The Arrogant One. Thesis Commons. DOI: https://doi.org/10.31237/osf.io/8nmku

Setiawan, Adib Rifqi. (2020, April 4). Grace Natalie Louisa. SocArXiv. DOI: https://doi.org/10.31235/osf.io/zwf6g

Setiawan, Adib Rifqi. (2020, April 4). Grace Natalie Louisa. Thesis Commons. DOI: https://doi.org/10.31237/osf.io/u3mxv

Setiawan, Adib Rifqi. (2020, April 3). Sharifah Halimah Alaydrus : a female preachers for our time. SocArXiv. DOI: https://doi.org/10.31235/osf.io/zb8qe

Setiawan, Adib Rifqi. (2020, April 2). Desain Pembelajaran untuk Membimbing Siswa Sekolah Dasar dalam Memperoleh Literasi Saintifik. EdArXiv. DOI: https://doi.org/10.35542/osf.io/u59f8

Setiawan, Adib Rifqi. (2020, April 2). What is the Best Way to Analyze Pre-Post Data?. EdArXiv. DOI: https://doi.org/10.35542/osf.io/h4e6q 
Setiawan, Adib Rifqi. (2020, April 2). JUPE My Uncut Story. Open Science Framework (OSF). DOI: https://doi.org/10.31219/osf.io/qdxga

Setiawan, Adib Rifqi. (2020, April 1). Syarifah Halimah Alaydrus. Thesis Commons. DOI: https://doi.org/10.31237/osf.io/xbmcs

Setiawan, Adib Rifqi. (2020, April 1). Sharifah Halimah Alaydrus. Thesis Commons. DOI: https://doi.org/10.31237/osf.io/fp79c

Setiawan, Adib Rifqi. (2019, October 8). Biografi Clara Ng Perempuan Penulis Asal Indonesia. PsyArXiv. DOI: https://doi.org/10.31234/osf.io/yk8sx

Setiawan, Adib Rifqi. (2019, December 23). Contoh Langkah Pembelajaran Berorientasi Literasi Saintifik. santrimilenial.net. URL: https://santrimilenial.net/contoh-langkah-pembelajaran-berorientasiliterasi-saintifik/

Setiawan, Adib Rifqi. (2019, June 14). Deasy Noviyanti, Perempuan Berbadan Defisit Lemak. qureta.com. URL: https://www.qureta.com/next/post/deasy-noviyanti-perempuan-berbadan-defisit-lemak

Setiawan, Adib Rifqi. (2018, December 18). Irma Rahma Suwarma. qureta.com. URL: https://www.qureta.com/next/post/irma-rahma-suwarma

Setiawan, Adib Rifqi. (2018, October 05). Karen Armstrong. qureta.com. URL: https://www.qureta.com/next/post/karen-armstrong

Setiawan, Adib Rifqi. (2018, September 17). Lola Zieta Azelien. qureta.com. URL: https://www.qureta.com/next/post/lola-zieta-azelien

Setiawan, Adib Rifqi. (2018, July 16). Rustriningsih, Srikandi Tersisih. qureta.com. URL: https://www.qureta.com/next/post/rustriningsih-srikandi-tersisih

Setiawan, Adib Rifqi. (2018, July 03). Tangis Daniela Hantuchová. qureta.com. URL: https://www.qureta.com/next/post/tangis-daniela-hantuchova

Setiawan, Adib Rifqi. (2018, June 28). Dewi Perssik. qureta.com. URL: https://www.qureta.com/next/post/dewiperssik

Setiawan, Adib Rifqi. (2018, June 27). Ice. qureta.com. URL: https://www.qureta.com/next/post/ice

Setiawan, Adib Rifqi. (2018, May 24). Fakhrun. qureta.com. URL: https://www.qureta.com/next/post/fakhrun

Setiawan, Adib Rifqi. (2018, April 10). Eny Rochmawati Octaviani: memberikan hiburan, menyuntikkan harapan. Majalah SANTRI, 8:15-18. URL: https://issuu.com/majalahsantri/docs/majalah_santri_8/17

Setiawan, Adib Rifqi. (2018, April 10). Busana: pemantas raga, pelaras jiwa. Majalah SANTRI, 8: 26-27. URL: https://issuu.com/majalahsantri/docs/majalah_santri_8/28

Setiawan, Adib Rifqi. (2018, April 10). Rosa Amalia Iqony: paduan yakin diri dan rendah hati. Majalah SANTRI, 8: 46. URL: https://issuu.com/majalahsantri/docs/majalah_santri_8/48

Setiawan, Adib Rifqi. (2018, March 25). Novi Kaka: Sahabat, Panutan, Pembimbing. qureta.com. URL: https://www.qureta.com/next/post/novi-kaka-sahabat-panutan-pembimbing

Setiawan, Adib Rifqi. (2018, March 21). Bidadari di Kesunyian itu Bernama Maria Sharapova. qureta.com. URL: https://www.qureta.com/next/post/bidadari-di-kesunyian-itu-bernama-maria-sharapova

Setiawan, Adib Rifqi. (2018, March 19). Airin Rachmi Diany, Lilin Penerang Masyarakat Urban. qureta.com. URL: https://www.qureta.com/next/post/airin-rachmi-diany-lilin-penerang-masyarakat-urban

Setiawan, Adib Rifqi. (2018, March 19). Kamu dalam Aku: A Brief Story of Park Bom. qureta.com. URL: https://www.qureta.com/next/post/kamu-dalam-aku-a-brief-story-of-park-bom

Setiawan, Adib Rifqi. (2018, March 19). Guru yang Menyapih: Catatan Perjalanan Pribadi Nong Darol Mahmada. qureta.com. URL: https://www.qureta.com/next/post/guru-yang-menyapih-catatan-perjalananpribadi-nong-darol-mahmada

Setiawan, Adib Rifqi. (2018, March 17). Maryam Musfiroh: An Educator for Our Time. qureta.com. URL: https://www.qureta.com/next/post/maryam-musfiroh-an-educator-for-our-time 
Setiawan, Adib Rifqi. (2018, March 15). Eny R. Octaviani. qureta.com. URL:

https://www.qureta.com/next/post/eny-r-octaviani

Setiawan, Adib Rifqi. (2018, March 14). Surely You're Joking, Mrs. Ilmy!. qureta.com. URL: https://www.qureta.com/next/post/surely-you-re-joking-mrs-ilmy

Setiawan, Adib Rifqi. (2018, March 14). Meniti Ilmuwati. qureta.com. URL: https://www.qureta.com/next/post/meniti-ilmuwati

Setiawan, Adib Rifqi. (2018, March 12). Clara Ng. qureta.com. URL: https://www.qureta.com/next/post/clara-ng

Setiawan, Adib Rifqi. (2018, March 11). Kisah Kasih Ayah di Balik Mata Najwa. qureta.com. URL: https://www.qureta.com/next/post/kisah-kasih-ayah-di-balik-mata-najwa

Setiawan, Adib Rifqi. (2018, March 11). Rosa Amalia Iqony. qureta.com. URL: https://www.qureta.com/next/post/rosa-amalia-iqony

Setiawan, Adib Rifqi. (2018, March 10). Venice Min. qureta.com. URL: https://www.qureta.com/next/post/venice$\min$

Setiawan, Adib Rifqi. (2018, March 09). Ketika YoonA Menyaksikan Real Madrid Menghempaskan PSG. qureta.com. URL: https://www.qureta.com/next/post/ketika-yoona-menyaksikan-real-madridmenghempaskan-psg

Setiawan, Adib Rifqi. (2018, March 09). Kepedulian Airin Rachmi Diany pada Pendidikan. qureta.com. URL: https://www.qureta.com/next/post/kepedulian-airin-rachmi-diany-pada-pendidikan

Setiawan, Adib Rifqi. (2018, March 09). Laila Fariha Zein (a.k.a. Uus atau Febi). qureta.com. URL: https://www.qureta.com/next/post/laila-fariha-zein-febi

Setiawan, Adib Rifqi. (2018, March 09). Pantat Perekat Umat. qureta.com. URL: https://www.qureta.com/next/post/pantat-perekat-umat

Setiawan, Adib Rifqi. (2018, March 09). Sisi Religi Grace Natalie. qureta.com. URL: https://www.qureta.com/next/post/sisi-religi-grace-natalie

Setiawan, Adib Rifqi. (2018, March 09). Asal Usul Nama Via Vallen. qureta.com. URL: https://www.qureta.com/next/post/asal-usul-nama-via-vallen

Setiawan, Adib Rifqi. (2018, March 07). Mengenal Oza Kioza. qureta.com. URL: https://www.qureta.com/next/post/mengenal-oza-kioza

Setiawan, Adib Rifqi. (2018, March 06). Menyoal Vokal Duo Serigala. qureta.com. URL: https://www.qureta.com/next/post/menyoal-vokal-duo-serigala

Setiawan, Adib Rifqi. (2018, March 06). Breast Capital. qureta.com. URL: https://www.qureta.com/next/post/breast-capital

Amatullah; \& Setiawan, Adib Rifqi. (2017, October 10). Nadirsyah Hosen: berkarya sebagai diaspora. Majalah SANTRI, 7: 56-59.URL: https://issuu.com/majalahsantri/docs/santri_edisi_7/58

Setiawan, Adib Rifqi. (2017, June 03). Dari Yuli Hingga Julia. qureta.com. URL: https://www.qureta.com/next/post/dari-yuli-hingga-julia-2

Setiawan, Adib Rifqi. (2017, June 02). Aisha. qureta.com. URL: https://www.qureta.com/next/post/aisha-humaira

Setiawan, Adib Rifqi. (2015, November 10). Kehidupan Asmara Hawking: raga lumpuh, jiwa masih bisa tersentuh. fisikanet.lipi.go.id. URL: http://www.fisikanet.lipi.go.id/utama.cgi?artikel\&1447145876\&2

Setiawan, Adib Rifqi. (2015, November 07). Dibalik Sampul Buku A Brief History of Time, agar pengetahuan tak hanya dinikmati ilmuwan. fisikanet.lipi.go.id. URL:

http://www.fisikanet.lipi.go.id/utama.cgi?artikel\&1446855103\&2

Setiawan, Adib Rifqi. (2015, November 03). Dibalik Nama Besar Albert Einstein: Dari Politik, Asmara, hingga Matematika. fisikanet.lipi.go.id. URL:

http://www.fisikanet.lipi.go.id/utama.cgi?artikel\&1446556354\&2

Setiawan, Adib Rifqi. (2015, October 31). Kurir Mikroskopis Alam Semesta bukan debu biasa. fisikanet.lipi.go.id. URL: http://www.fisikanet.lipi.go.id/utama.cgi?artikel\&1446304060\&2

Setiawan, Adib Rifqi. (2015, October 10). 10 Kejutan Subatomik. fisikanet.lipi.go.id. URL: http://www.fisikanet.lipi.go.id/utama.cgi?artikel\&1444577286\&3 